\title{
Mitigating Consumptive Behavior By Enhancing Student's Financial Literacy: Experiments Using Video Learning
}

\section{Suparti, Dodik Juliardi, Hendry Praherdhiono, Mohamad Arief Rafsanjani}

Accounting, Faculty of Economy, State University of Malang

\section{Abstract}

In Indonesia, low level of financial literacy, which is reflected through consumptive behavior, has reached a point of concern. This study attempts to increase financial literacy among accounting students by using learning video. Learning video was used to increase financial literacy and decrease the consumptive behavior among students. This research used quasi experiment method in two classes (experiment class and

Corresponding Author:

Suparti

suparti_andi@yahoo.com

Received: 23 January 2018

Accepted: 5 April 2018

Published: 23 April 2018

Publishing services provided by Knowledge

(c) Suparti et al. This article is distributed under the terms of the Creative Commons

Attribution License, which permits unrestricted use and redistribution provided that the original author and source are credited.

Selection and Peer-review under the responsibility of the $15 t$ IRCEB Conference Committee.

\section{G OPEN ACCESS} control class). The findings indicate that video, as learning media, has a significant positive effect and can increase students' financial literacy as well as decrease the consumptive behavior of students.

Keywords: Financial Literacy, Consumptive Behavior, Video Learning.

\section{Background}

Nowadays, financial literacy becomes a concern of many people. Some studies have shown that more and more people have low financial literacy in some countries in Europe, America, Australian and other countries, including developing countries $[2,10]$. The same thing also occurs in Indonesia, in which the results of a survey which was conducted by the Financial Services Authority (0JK) show low level of financial literacy of Indonesians in 2016 , which is only $29.66 \%$ [14].

Low financial literacy will affect many things, one of which is a person's financial behavior, reflected through consumptive behavior $[3,5,10]$. Therefore, this needs a serious attention and concern of all parties, including academicians. This is because in developing countries, college has a significant contribution to national development $[12,16]$.

The learning process in college is one of the important factors in forming of student financial literacy. Financial learning in college has a significant influence on knowledge and financial skills of students [9]. Various methods, media, and learning resources 
are expected to give students knowledge and understanding in the field of finance or often referred to as financial literacy [11]. Therefore, college need to design an effective learning to improve financial literacy so as to reduce the consumptive behavior of students. In order to achieve the purpose of personal finance learning effectively, the learning media used should be appropriate.

The rapid development of technology encourages educators (lecturers) to utilize technology in classroom learning activities to support the achievement of learning objectives [17]. One of the technological developments that can be used in the learning process is video. The use of video in the learning process has many benefits, namely developing a student's knowledge base, improving students' understanding and discussion, accommodating diverse learning styles of students, as well as improving students' motivation and enthusiasm $[4,15]$. Another study has shown that learning videos can be stored and reused at any time, which can be used as learning materials for independent learners and can be used for distance learning [13].

Well packaged learning videos can convey more real information; provide a new style of education, encourage curiosity and can be adjusted to the ability of learners; help view the topic with a broader perspective $[1,6,8,15]$.

Based on the background above, the research questions of this research are as follows:

1. Is there any effect of using instructional video media on students' financial literacy and consumptive behavior?

2. Can the use of learning video media improve students' financial literacy and consumptive behavior?

\section{Method}

Quasi experiment method is used in this research to see the effect of using video learning media on students' financial literacy and its impact on students' consumptive behavior. Financial literacy and consumptive behavior were measured by using an instrument which was developed by Danes \& Haberman, (2007). The constructs for financial literacy are understanding the cost of buying on credit, knowing key questions to ask when shopping for auto insurance, knowing about investments (stocks, mutual funds, bonds, etc), and knowing the difference between needs and wants. While the constructs for consumptive behavior are tracking the expenses, comparing the prices, 
set aside money for future, using a budget, repay the money owed on time, writing financial goals, achieving financial goals, and discussing money with family.

This research uses two groups of accounting students at Universitos Negeri Malang with the same characteristics (ability, knowledge level/ financial literacy, location of learning, and qualification of teaching staff). The first group is experimental group. This group used a lecture model with learning video as the media, which have been prepared before and guided by a lecturer. The other group is a control group that was taught by using the conventional discussion model with Microsoft Office Power point as the learning media, which is also guided by a lecturer.

At the beginning of the study, those two groups would be given a pre-test. Next, the experimental group is given treatment of personal finance video (as the learning media) and control group was taught by using Microsoft Office Power point as the learning media. At the end of the study, both groups would be given a post-test. Pretest and post-test is used to determine the level of financial literacy and consumptive behavior of students.

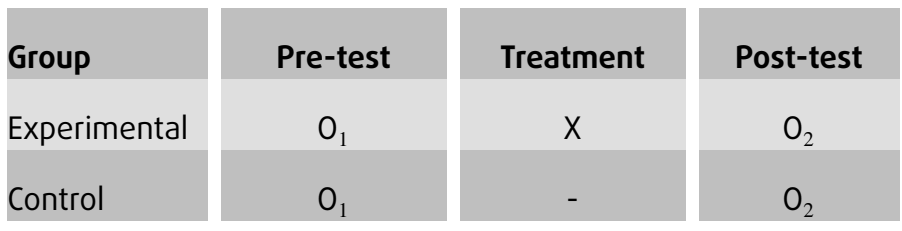

Figure 1: Research Design.

The pre-test and post-test results of these two groups would then be analyzed by using t-test to see the effect of using video as the learning media on financial literacy and its impact on students' consumptive behavior. Analysis conducted in this study include several stages: First, the pre-test score in difference test (t-test) was used to ensure that students from both classes (experimental and control class) have the same level (equivalent) of students' financial literacy and consumptive behavior.

Second, we compared the mean of pre-test and post-test scores of each class to see whether there was an increase in the level of financial literacy and consumptive behavior after the treatment was given, followed by a t-test to see the significance of the increase in pre-test score to the post-test score.

Third, we compared the mean of post-test scores of experimental class and control class to see which class having the higher post-test score. Furthermore, a difference test (t-test) was conducted on the gain score to see whether there were significant differences from those two classes, which would be used as a basis to conclude whether there is influence of treatment given. 


\section{Findings}

Researchers performed the analysis in several stages. First, we analyzed the pre-test results of experimental class and control class by using difference test (t-test) to see if there were differences in the level of financial literacy and consumptive behavior of the students in those two classes (subject of our study). The results can be seen in table 1 below:

TABLE 1: T-test results of pre-test score of financial literacy and consumptive behavior variable.

\begin{tabular}{|c|c|c|}
\hline \multicolumn{2}{|c|}{ Variable } & t-test for Equality of Means \\
\hline $\begin{array}{l}\text { Financial } \\
\text { Literacy }\end{array}$ & $\begin{array}{c}\text { Equal variance } \\
\text { assumed }\end{array}$ & 0,893 \\
\hline $\begin{array}{l}\text { Consumptive } \\
\text { Behavior }\end{array}$ & $\begin{array}{l}\text { Equal variance } \\
\text { assumed }\end{array}$ & 0,279 \\
\hline
\end{tabular}

The results of difference test on pre-test score before the treatment was given (in table 1) show that there was no significant difference in the level of financial literacy and consumptive behavior among the students in both classes (experimental class and control class) who became the subject of our study (sig>0.05).

Second, after giving treatment in each class, lecturers in the experimental class provided personal finance material by using video as the learning media, while in control class, teaching and learning activity was conducted conventionally (lectures and discussions) with Microsoft Office Power point as the learning media. The researchers conducted post-test to determine the level of financial literacy and consumptive behavior of students. The researchers then compared the mean of the pre-test and post-test scores of each class to see whether there was an increase in students' level of financial literacy and consumptive behavior after the treatment was given. The results can be seen in table 2 and table 3 below:

TABLE 2: Comparison of the mean of pre-test and post-test scores.

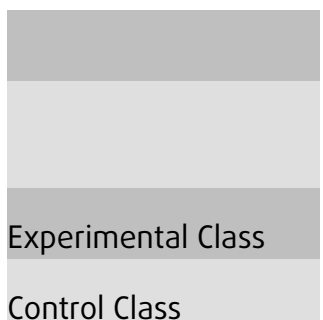

Control Class

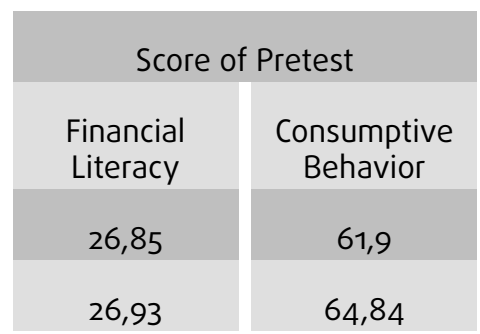

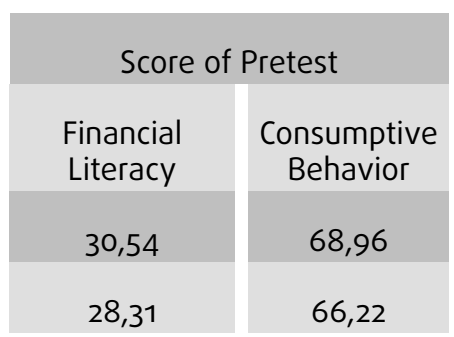

Table 2 above shows that the post-test score is higher than the pre-test score. To more convince us, a follow-up test namely difference test (t-test) was conducted to 
see if the post-test score is significantly different from the pre-test score. The results are shown in table 3 below:

TABLE 3: Pre-test and post-test $t$ test results in the experimental class and control class.
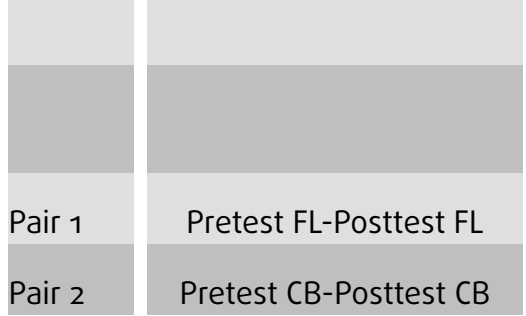

\begin{tabular}{c|c}
\multicolumn{2}{|c}{ Sig. (2-tailed) } \\
$\begin{array}{c}\text { Experimental } \\
\text { Class }\end{array}$ & Control Class \\
\hline 0,000 & 0,000 \\
\hline 0,000 & 0,000 \\
\hline
\end{tabular}

Difference test results in table 3 above shows that the pre-test scores are different from post-test scores significantly (sig <.05). This indicates that learning by using video as learning media which was conducted in the experimental class increases students' level of literacy and decrease students' consumptive behavior.

Third, the researchers compared the mean of post-test scores of the experimental class and control class to see which grade obtaining the higher post-test score. The results can be seen in table 4 below:

TABLE 4: Comparison of mean of post-test score of the experimental class and control class.

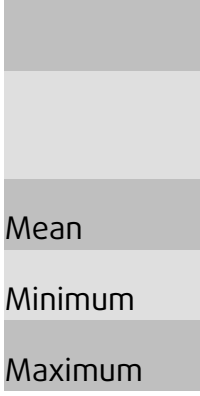

Experime
Financial
Literacy
30,54
25,00
36,00

Consumptive
Behavior
68,96
49,00
102,00

\begin{tabular}{|c|c|}
\hline \multicolumn{2}{|c|}{ Control Class } \\
\hline $\begin{array}{c}\text { Financial } \\
\text { Literacy }\end{array}$ & $\begin{array}{c}\text { Consumptive } \\
\text { Behavior }\end{array}$ \\
\hline 28,31 & 66,22 \\
\hline 21,00 & 39,00 \\
\hline 37,00 & 93,00 \\
\hline
\end{tabular}

The result of table 3 above can show that the mean of post-test scores achieved by experimental class is higher than the mean of post-test scores achieved by control class. Furthermore, a t-test was performed on the gain score to see whether there is a significant difference from the second post-test scores of both classes. The results can be seen in table 5 below:

TABLE 5: Results of difference test on the gain score of experimental class and control class.

\begin{tabular}{l|l} 
& Variable \\
$\begin{array}{l}\text { Financial } \\
\text { Literacy } \\
\text { Consumptive } \\
\text { Behavior }\end{array}$ & $\begin{array}{c}\text { Equal variance } \\
\text { assumed }\end{array}$ \\
\hline
\end{tabular}

$\frac{\mathrm{t} \text {-test for Equality of Means }}{\text { sig. (2-tailed) }}$
0,000
0,000


The results of difference test on the gain score in table 5 above shows that both variables have sig value $<0,05$ which shows that statistically there is a significant difference of gain score obtained by experiment class and control class both at students' financial literacy level and consumptive behavior. This indicates that there is influence of the use of video as the learning media on the level on financial literacy and consumptive behavior of students. The existence of this influence can be seen from the existence of significant difference of score between class which was taught by using video as the learning media (experimental class) and class which was taught by using Microsoft Office Power point as learning media (control class).

\section{Discussion}

After treatment was given in each class, the researchers compared the mean of the pre-test and post-test scores of the two classes. Table 2 above shows that there is an increase in the score of financial literacy and consumptive behavior. Results of t-test (table 3) also confirm that there is a significant difference between pre-test and posttest score. Then, we compared the mean of post-test score achieved by students of the experimental class and the mean of post-test score achieved by students of control class (table 4 ), showing that the mean of post-test scores achieved by students of the experimental class is higher than the mean of post-test scores achieved by students of control class, followed by t-test on the gain score (table 5), showing that there is statistically significant difference in gain scores achieved by the experimental class and control class, both at the level of financial literacy and consumptive behavior of students.

This shows that there is a positive influence of the use of video as learning media on the level of financial literacy and consumptive behavior of students. The existence of this influence can be seen from the significant difference of gain scores between class which was taught by using video as the learning media (experimental class) with class which was taught by using Microsoft Office Power point as the learning media (control class).

These results support the previous findings that financial learning in college is one of the important factors in forming the financial literacy of students. Financial learning in college has a significant influence on students' financial knowledge and skills [9]. The findings also show us that the use of certain strategies, such as the use of video as the learning media, can improve the knowledge of students, which in this case is financial literacy. This is in line with some of the previous findings [11, 17]. 
This study also supports the previous findings that the use of video as the learning media can convey more tangible information; provide new educational styles and encourage learners' curiosity $[1,6,8,15]$. It is proven in this research that the achievement level of experiment class is better and significantly different from the control class. In the experimental class, the lecturer taught by using the video as the learning media, while in the control class the lecturer taught by using conventional method, lectures and discussions, without using any media.

Low financial literacy in many countries, both developed countries and developing countries, including in Indonesia [2, 10, 14] will affect many things, one of which is the financial behavior of a person, which is reflected through consumptive behavior $[3,10]$. It needs to be taken seriously by us, academicians in college. This is because college has a significant contribution to national development $[12,16]$. The findings of this study show that if we have concerns to improve students' knowledge, especially in financial literacy and consumptive behavior, we need to design an effective learning; therefore, the purpose of learning can be achieved effectively. This study shows that the use of video as learning media can achieve the learning objectives.

\section{Conclusion}

The use of learning video media has a significant positive effect on the level of financial literacy, and ultimately can decrease the consumptive behavior of students. It emphasizes to us as teachers that effective learning can be designed by using certain strategy or media, so that the purpose of learning can be achieved well.

\section{Limitation}

This study was conducted on accounting students, so for the purposes of generalization in other majors, further study is needed due to differences in students' characteristics and level of financial literacy owned.

\section{References}

[1] Aloraini, S. (2012). The impact of using multimedia on students' academic achievement in the College of Education at King Saud University. Journal of King Saud University - Languages and Translation, 24(2), 75-82. https://doi.org/10.1016/j . jksult.2012.05.002 
[2] Atkinson, A. \& F. Messy. (2012). Measuring Financial Literacy: Results of the OECD / International Network on Financial Education (INFE) Pilot Study. OECD Working Papers on Finance, Insurance and Private Pensions, No. 15. https://doi.org/http://dx. doi.org/10.1787/5k9csfs90fr4-en

[3] Chinen, K., \& Endo, H. (2014). Observation of Financial Literacy among the Selected Students in the U.S. and Japan. International Journal of Economics and Finance, 6(9), 95. https://doi.org/10.5539/ijef.v6n9p95

[4] Cruse, Emily. (2006). Using Educational Video in the Classroom: Theory, Research and Practice /Media and Learning. Retrieved August 30, 2017, from http://www. libraryvideo.com/articles/article26.asp

[5] Danes, S. M., \& Haberman, H. R. (2007). Teen financial knowledge, self-efficacy, and behavior: A gendered view. Journal of Financial Counseling and Planning, 18(2), 48-60.

[6] Holsinger, Erik. (1995). How do multimedia works (Vol. 1). Riyadh: Arab Scientific Publishers.

[7] Hilgert, M. A., Hogarth, J. M., \& Beverly, S. G. (2003). Household financial management: the connection between knowledge and behavior. Federal Reserve Bulletin, (Jul), 309-322.

[8] Alfar, Ibrahim. (2009). Preparation and production of interactive multimedia software (1st ed.). Egypt: Delta Computer Technology.

[9] Johnson, E., \& Sherraden, M. (2007). From Financial Literacy to Financial Capability Among Youth. The Journal of Sociology \& Social Welfore, 34(3). Retrieved from http: //scholarworks.wmich.edu/jssw/vol34/iss3/7

[10] Lusardi, A \& Mitchell, OS. (2014). The Economic Importance of Financial Literacy:Theory and Evidence. Journal of Economic Literature, 52(1), 5-44. https://doi. org/http://dx.doi.org/10.1257/jel.52.1.5

[11] Lutfi, \& Iramani. (2008). Financial Literacy Among University Students And Its Implications To The Teaching Method. Presented at the SEAAIR Conference, STIE Perbanas Surabaya.

[12] Aligaweesa, Millicent A.k. (1987). The role of a university in national development: a case study of makerere university. Journal of Educational Administration, 25(2), 294-307. https://doi.org/10.1108/eboog937

[13] Mohamad, Rossafri, Yahaya, Wan Ahmad Jaafar Wan, \& Muninday, Balakrishnan. (2008). USING VIDEO MATERIALS IN FORMAL EDUCATION: A METHODOLOGICAL APPROACH. Retrieved August 30, 2017, from https://www.researchgate.net/ 
publication/265466001_USING_VIDEO_MATERIALS_IN_FORMAL_EDUCATION_A_ METHODOLOGICAL_APPROACH

[14] OJK. (2017). Survei Nasional Literasi dan Inklusi Keuangan. Kemeterian Keuangan Republik Indonesia. Retrieved from http://www.ojk. go.id/id/berita-dan-kegiatan/siaran-pers/Documents/Pages/ Siaran-Pers-0JK-Indeks-Literasi-dan-Inklusi-Keuangan-Meningkat/17 . 01 . 23\%20Tayangan $\% 20 \% 20$ Presscon $\% 20 \% 20$ nett. compressed. pdf

[15] Qandeel, Abdul Rahman Yasin. (1998). Educational Methods and Technology Education (Vol. 1). Riyadh: Riyadh Publishing House.

[16] Ross, A. M. (1973). The Role of Higher Education Institutions in National Development. Higher Education, 2(1), 103-108. https://doi .org/10.2307/3445764

[17] Smaldino, Sharon E., Lowther, Deborah L., \& Russel, James D. (2015). Intructional technology \& Media For Learning. USA: Pearson. 